\title{
Surface Active Rubidium Carbonate Obtained from The Thermal Decomposition Course of Rubidium Acetate
}

Basma A. A. Balboul

Chemistry Department, Faculty of Science, Minia University, El-Minia 61519, Egypt.

\begin{abstract}
T HE THERMAL decomposition course of rubidium acetate $\mathrm{Rb}\left(\mathrm{CH}_{3} \mathrm{COO}\right)$ was probed on heating up to $1000{ }^{\circ} \mathrm{C}$ in a dynamic atmosphere of air by thermogravimetry and differential thermal analysis. The solid and gas-phase decomposition products were identified by X-ray diffractometry, ex- and in-situ infrared spectroscopy and mass spectrometry. Results obtained showed the acetate to decompose stepwise to yield eventually $\mathrm{Rb}_{2} \mathrm{O}$ at $\geq 900{ }^{\circ} \mathrm{C}$ encompassing the formation of the intermediate $\mathrm{Rb}_{2} \mathrm{CO}_{3}$ solid product (at $400-700{ }^{\circ} \mathrm{C}$ )) and $\mathrm{H}_{2} \mathrm{O},\left(\mathrm{CH}_{3}\right)_{2} \mathrm{CO}$ and $\mathrm{CO}_{2}$ as primary gaseous products. A considerable enhancement of the production of primary gas phase products at $400-450{ }^{\circ} \mathrm{C}$ and the emergence of $\left(\mathrm{CH}_{3}\right)_{2} \mathrm{C}=\mathrm{CH}_{2}, \mathrm{CH}_{4}$ and $\mathrm{CO}$ molecules in the gas phase are ascribed to reactions occurring at the gas/solid interface at the expense of some of the primary products. The activity at the gas solid interface has been indicated These interfacial activities impart application-worthy adsorptive and catalytic functions for the associated solid products.
\end{abstract}

Keywords: Rubidium acetate, Rubidium carbonate, Infrared spectroscopy, Thermal analysis and Gas/solid interfacial reactivity.

Metal acetates are useful reagents, particularly in organic synthesis and in the preparation of some industrially important metal and metal oxide catalysts ${ }^{(1-3)}$.

Acetate compounds are easily prepared for a large number of metals. Their thermal decomposition, under various conditions ${ }^{(1,4)}$, has acquired a profound importance, for its intimate relevance to various research areas in the solid state and surface chemistry. Numerous studies have been published on the thermal decomposition of metal acetates e.g., ${ }^{(1,4-7)}$ most of which have been focused on reaction stoichiometry, influence of temperature on product yields, and nature of the solid products formed, effect of decomposition atmosphere ${ }^{(8)}$. Consequently, nature of gaseous products and their chemical reactivity at the gas/solid interface have not received sufficient attention ${ }^{(9)}$.

Results of the above referred to studies have led to two general conclusions. First, the major gaseous product of metal acetate decomposition is either acetone or acetic acid. Second, the decomposition products are not always those formed primarily in the initial stages, and may be due to reactions between the primary 
products. slowly removed gaseous products may get involved in surfacemediated, uni- and/or bimolecular side reactions throughout the decomposition course $^{(1,9,10)}$. In a different approach, Mekhemer et al. ${ }^{(10)}$ have reported IRobservation of the consumption of acetone gas molecules, being released by decomposing magnesium acetate, due to involvement in aldol-condensation-type of reactions on surfaces of $\mathrm{MgO}$ thus yielded.

It is this latter conclusion that has been at the focus of attention of the present and a few previous investigations ${ }^{(10-12)}$.

Alkali metals and metal oxides are among the strongest bases known, both rubidium and cesium oxides have been reported to be "superbases" ${ }^{(13)}$. These oxides have a very low surface area that limits their ability to be effective catalysts. Doping of various alkali metal salts on $\mathrm{MgO}$ produces both basic and superbasic catalysts used for the oxidative coupling of methane and the aldol condensation of acetone ${ }^{(14)}$. In a recent study, the effect of $\mathrm{Rb}$ and Cs carbonates (carbonate solutions $(1 \mathrm{M})$ ) for production of phenols from liquefaction of wood biomass have been reported. The catalytic hydrothermal treatment of wood biomass produced mainly phenolic compounds and benzenediol derivatives ${ }^{(15)}$.

Therefore, the present investigation was designed to explore the thermal decomposition course of Rubidium acetate, $\mathrm{Rb}\left(\mathrm{CH}_{3} \mathrm{COO}\right)$, and the reactivity at the gas/solid interface. Up to the best of my knowledge, thermal decomposition characteristics of the test acetate has not been reported, though it might be an appropriate precursor for the synthesis of catalytic Rubidium oxide and /or Rubidium carbonate. To accomplish the present research objectives: (i) thermal events involved in the decomposition course were revealed by thermogravimetry and differential thermal analysis, (ii) the solid and gas phase decomposition products were identified by X-ray powder diffractometry, Fourier-transform infrared spectroscopy and gas-mass spectrometry, and (iii) reactivity at the gas/solid interface established throughout the decomposition course was assessed by in-situ FT-IR gas phase spectra taken from an environment of accumulating gaseous products, so as to simulate conditions of a slow removal of these products.

\section{The rubidium acetate}

\section{Experimental}

Rubidium acetate $\left(\mathrm{Rb}\left(\mathrm{CH}_{3} \mathrm{COO}\right)_{3}\right.$; denoted $\left.\mathrm{RbAc}\right)$ was a $99.99 \%$ pure product of Aldrich (USA). Based on the thermal analysis results (vide infra), decomposition solid products were obtained by calcination at $200^{\circ}-950{ }^{\circ} \mathrm{C}$ (for $1 \mathrm{hr}$ ) of RbAc, in a still atmosphere of air, and kept dry till further use. These decomposition products are indicated throughout the text by the acetate

Egypt. J. Chem. 54, No. 4 (2011) 
designation followed by the temperature applied. For example, RbAc500 indicates the solid product yielded at $500{ }^{\circ} \mathrm{C}$.

\section{Apparatus and methods}

Thermogravimetry (TG) and differential thermal analysis (DTA) were performed by a $30 \mathrm{H}$ Shimadzu analyzer (Japan), on heating small portions (10$15 \mathrm{mg}$ ) of the acetate up to $1000{ }^{\circ} \mathrm{C}$ (at $10{ }^{\circ} \mathrm{C} / \mathrm{min}$ ) in a dynamic atmosphere of air $\left(50 \mathrm{~cm}^{3} / \mathrm{min}\right)$. A highly sintered $\alpha-\mathrm{Al}_{2} \mathrm{O}_{3}$ (Shimadzu Corp.) was the thermally inert reference material used for the DTA.

X-ray powder diffractometry (XRD) was carried out by means of a model JSX-60 PA Jeol diffractometer (Japan) equipped with Ni-filtered $\mathrm{CuK} \alpha$ radiation $(\lambda=0.15416 \mathrm{~nm})$. Based on scans in the range $4^{\circ} \leq 2 \theta \leq 60^{\circ}$, the $2 \theta$ and relative intensity $\left(\mathrm{I} / \mathrm{I}^{\circ}\right)$ values were obtained for the observed diffraction peaks and matched with those filed in the JCPDS database ${ }^{(16)}$ for phase identification purposes.

Ex- and in-situ FTIR spectra were measured at $4000-400 \mathrm{~cm}^{-1}$ with the resolution of $4 \mathrm{~cm}^{-1}$, using a model 410 Jasco FT-IR spectrophotometer (Japan). The ex-situ spectra were taken of lightly loaded $(<1 \%)$ thin discs of $\mathrm{KBr}$ supported test materials. Whereas, the in-situ spectra were taken of the gas phase being released while heating at various temperatures $\left(200-700{ }^{\circ} \mathrm{C}\right.$, for $\left.5 \mathrm{~min}\right)$ of a 500 -mg portion of the acetate material mounted inside a specially designed IRcell ${ }^{(17)}$ equipped with $\mathrm{CaF}_{2}$ windows. The cell, mounting the test acetate portion, was briefly evacuated of air prior to heating and recording of the gas phase spectra.

\section{Results and Discussion}

Thermal events in the acetate decomposition course

TG and DTA curves obtained on heating (in air) of $\mathrm{RbAc}$ up to $950{ }^{\circ} \mathrm{C}$ (at $10^{\circ} \mathrm{C} / \mathrm{min}$ ) are shown in Fig.1. The decomposition course of the acetate commences near $300{ }^{\circ} \mathrm{C}$ and terminates at $\geq 900{ }^{\circ} \mathrm{C}$ bringing the total ML up to $35.5 \%$ which is satisfactorily close to that (36\%) expected for $\mathrm{Rb}\left(\mathrm{CH}_{3} \mathrm{COO}\right)$ $\mathrm{Rb}_{2} \mathrm{O}$ transformation. The shaded area represents $\mathrm{ML}$ due to removal of physisorbed water as a result of the hygroscopic nature of the acetate sample.

The TG curves results brought about resolve four ML thermal events (II- V). These events and their characteristics are set out in Table 1. Considering the DTA curve (Fig. 1), the results obtained resolve three endothermic and two exothermic effects occurring in the temperature range $220-900{ }^{\circ} \mathrm{C}$. The first endothermic event maximized at $238{ }^{\circ} \mathrm{C}$, is due to mass invariant melting process, preceding decomposition of RbAc via event II. 
TABLE 1. Characteristics of thermal events encountered (Fig. 1) throughout the RbAc decomposition course (at $10 \mathrm{oC} / \mathrm{min}$ ) in air.

\begin{tabular}{|c|c|c|c|c|}
\hline $\begin{array}{c}\text { Thermal } \\
\text { event }\end{array}$ & $\begin{array}{c}\text { Temperature } \\
\text { range/ }{ }^{\mathbf{0}} \mathbf{C}\end{array}$ & $\mathbf{T}_{\max } /{ }^{\mathbf{0}} \mathbf{C}$ & $\begin{array}{c}\text { Mass loss } \\
\mathbf{\%}\end{array}$ & $\Delta \mathbf{T} / \mathbf{T}$ \\
\hline $\mathrm{I}^{\mathrm{a}}$ & $215-250$ & 238 & & endo \\
\cline { 3 - 5 } $\mathrm{II}^{\mathrm{b}}$ & $420-520$ & 435 & & endo \\
\hline \hline $\mathrm{III}^{\mathrm{b}}$ & & 478 & & exo \\
\hline $\mathrm{IV}^{\mathrm{b}}$ & & 499 & 19.8 & exo \\
\cline { 3 - 5 } $\mathrm{V}$ & & 750 & & endo \\
\hline \hline
\end{tabular}

${ }^{a}$ Event $\mathrm{I}$ is mass invariant process.

${ }^{\mathrm{b}}$ Events II, III and IV are strongly overlapping in mass loss.

${ }^{\mathrm{c}}$ Cumulative mass loss.

The solid and gas phase products yielding throughout the decomposition course were identified and the results must be compared to the TG and DTA results, in order to reveal the physicochemical nature of the processes.

\section{Product analysis}

The IR gas phase analysis results are given in Fig. 2, whereas, XRD and IR analysis results obtained for RbAc decomposition solid products are shown in Fig. 3 and 4, respectively.

The gas phase composition of $\mathrm{RbAc}$ at $200{ }^{\circ} \mathrm{C}$ gave rise to the IR spectrum (Fig. 2), indicating the presence of absorptions due to $v \mathrm{OH}$ (at $3415 \mathrm{~cm}^{-1}$ ) and $\delta \mathrm{OH}\left(\right.$ at $\left.1622 \mathrm{~cm}^{-1}\right)$ of water molecules ${ }^{(18,19)}$. The presence of water molecules in RbAc sample may be attributed to the hygroscopic nature of the substance, which causes absorption of moisture during handling of the material and preparation of IR gas test sample.

The IR gas phase of RbAc400 (Fig. 2) shows weakening of water absorption at $\left(3407\right.$ and $\left.1622 \mathrm{~cm}^{-1}\right)$ with the appearance of weak absorptions of weak shoulders at $\left(1025,1205,1710,1725 \mathrm{~cm}^{-1}\right)$ assignable to acetate groups ${ }^{(18)}$. The detection of acetic acid molecules in the gas phase, upon heating up to $400{ }^{\circ} \mathrm{C}$, may be attributed to ${ }^{(11)}$ water-assisted hydrolytic removal of acetate groups $\left(\mathrm{CH}_{3} \mathrm{COO}_{\mathrm{s}}^{-}+\mathrm{H}_{2} \mathrm{O}_{\mathrm{g}} \longrightarrow \mathrm{CH}_{3} \mathrm{COOH}_{\mathrm{g}}+\mathrm{OH}_{\mathrm{s}}^{-}\right.$, and/ or the formation of rubidium hydroxy acetate through the transformation

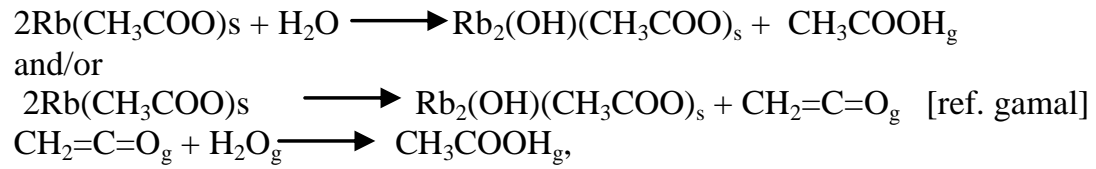

where $s$ and $g$ stand for solid and gas, respectively)

Moreover, the emergence of absorptions (at 2344 and $\sim 670 \mathrm{~cm}^{-1}$ ), respectively due to the fundamental vibrations of $\mathrm{CO}_{2}$ molecules ${ }^{(20)}$ and $\mathrm{CO}$ (at $2135 \mathrm{~cm}^{-1}$ ). This hydrolytic processes may explain the slow ML monitored by the slopping plateau (Fig. 1) shown to lead to significant ML accompanying the strongly overlapping thermal events II, III and IV. 
Fig. 2. In-situ IR spectra taken from the gas-phase accumulated at the temperatures indicated (for $5 \mathrm{~min}$ ) throughout the decomposition course of a 500-mg portion of RbAc mounted inside a specially designed cell.

Egypt. J. Chem. 54, No. 4 (2011) 
Fig. 3. Ex-situ IR spectra taken from RbAc and its designated solid-phase decomposition products. 
Fig. 4. X-ray powder diffractograms obtained for RbAc and its designated solidphase decomposition products.

The thermal events II, III and IV (maximized at 435,478 and $499{ }^{\circ} \mathrm{C}$ ) lead to total ML (19.8- $20.0 \%$ ) very close to that $(20.1 \%)$ expected for the formation of $\mathrm{Rb}_{2} \mathrm{CO}_{3}$. The ML detected for event III which is (14.5-14.7\%) is comparable to the theoretical ML (14.5\%) for the formation of the unstable intermediate $\mathrm{Rb}_{2}(\mathrm{OH})\left(\mathrm{CH}_{3} \mathrm{COO}\right)$. Whereas, the observed ML of the second exothermic step is (19.8- 20\%) comparable to (20.1\%), for the formation of $\mathrm{Rb}_{2} \mathrm{CO}_{3}$ at $\sim 520{ }^{\circ} \mathrm{C}$ via the following reaction:

$$
\mathrm{Rb}_{2}(\mathrm{OH})\left(\mathrm{CH}_{3} \mathrm{COO}\right) \quad \longrightarrow \quad \mathrm{Rb}_{2} \mathrm{CO}_{3}+\mathrm{CH}_{4}
$$

Compatibly, The IR spectrum taken from the decomposition solid- phase product $\mathrm{RbAc500}$ (Fig. 4) is dominated by diagnostic absorptions of various modes of vibrations of bulk $\mathrm{CO}_{3}{ }^{2-}$ species; viz. at 1640, 1406, 1384, 1008, 830, 
702 and $450 \mathrm{~cm}^{-1(18-20)}$. XRD pattern RbAc500 (Fig. 4) displays peaks that match the standard pattern for $\mathrm{Rb}_{2} \mathrm{CO}_{3}$ compiled in JCPDS 71-1980

In support to the above results, the gas phase spectrum at $500{ }^{\circ} \mathrm{C}$ (Fig.2) has considerable modifications (i) reinforcement of peaks characteristic for acetic acid molecules (ii) emergence of weak diagnostic absorptions (at 1737, 1375, 1220) ${ }^{(20,21)}$ for acetone molecules and absorptions (at 3740, 3605 and $2344 \mathrm{~cm}^{-1}$ ) for $\mathrm{CO}_{2}$ molecules ${ }^{(20)}$ (iii) monitoring the emergence of weak absorptions assignable to $\mathrm{CH}_{4}$ (at 3010, 1510 (doublet) and $\left.1245 \mathrm{~cm}^{-1}\right)^{(21)}$ and CO (at $2135 \mathrm{~cm}^{-1}(20)$ ).

The emergence of acetone and $\mathrm{CO}_{2}$ molecules at this stage may be explained by the decarboxylative coupling (ketonization) of the acetic acid molecules via the reaction :

$$
\left(2 \mathrm{CH}_{3} \mathrm{COOH}_{\mathrm{g}} \longrightarrow\left(\mathrm{CH}_{3}\right)_{2} \mathrm{CO}_{\mathrm{g}}+\mathrm{CO}_{2 \mathrm{~g}}+\mathrm{H}_{2} \mathrm{O}_{\mathrm{g}}\right)
$$

The gas phase composition at $600{ }^{\circ} \mathrm{C}$ (Fig.2) revealed the complete transformation of acetic acid molecules to acetone molecules (ketonization) which is confirmed by the strong absorptions appeared at $(1737,1450,1375$ and $1220 \mathrm{~cm}^{-1}$ ). The spectrum also, revealed the reinforcement of the absorptions characteristic to $\mathrm{CO}_{2}, \mathrm{CO}$ and $\mathrm{CH}_{4}$ molecules. New bands at 2965 and $890 \mathrm{~cm}^{-1}$ characteristic to isobutene $\left(\mathrm{CH}_{3}\right)_{2} \mathrm{C}=\mathrm{CH}_{2}$ molecules have been observed. It is obvious that the increase in the amount of these gaseous products is on the expense of acetic acid molecules formed at lower temperatures during heating the acetate sample. The suggested catalytic ketonization of carboxylic acids molecules on metal oxides have been reported previously ${ }^{(10,23,24)}$. They attributed the catalytic ketonization to $\mathrm{Rb}-\mathrm{O}$ sites exposed on the carbonate formed in the solid product. The fact that surface carbonate species established during the ketonization course on metal oxide surfaces has been considered to be the surface intermediate to the release of $\mathrm{CO}_{2}$ molecules into the gas phase ${ }^{(10)}$, may lend a strong support to the present suggestion.

The formation of isobutene $\left(\left(\mathrm{CH}_{3}\right)_{2} \mathrm{C}=\mathrm{CH}_{2}\right)$ may, according to Zaki and Sheppard ${ }^{(25)}$, be attributed to the involvement of acetone molecules into bimolecular surface reactions releasing isobutene into the gas phase and leaving behind bridge-bonded acetate surface species:

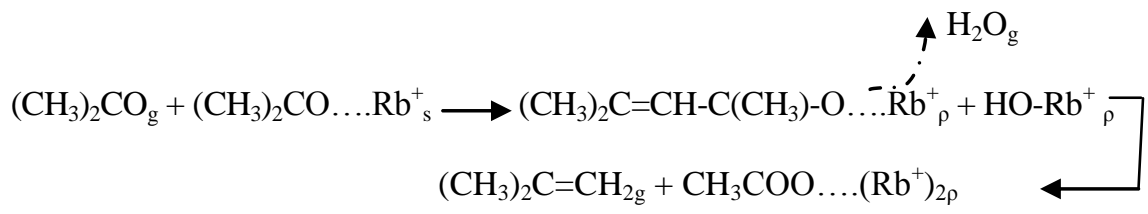

The IR spectra obtained for the gas phase accumulated at $700{ }^{\circ} \mathrm{C}$ (Fig. 2) indicate the disappearance of the diagnostic absorptions of acetone, water and isobutene molecules, a slight weakening of those of $\mathrm{CO}_{2}$ molecules, and the 
intensification of the absorptions of $\mathrm{CH}_{4}$ (at 3010, 1510 (doublet) and 1245 and $940 \mathrm{~cm}^{-1(26)}$ ) and CO (at $2133 \mathrm{~cm}^{-1}$ ) molecules.

TG curve (Fig.1) shows slow ML in the temperature range $550-750{ }^{\circ} \mathrm{C}$ preceding the last observed thermal event $\mathrm{V}$ at $\sim 850{ }^{\circ} \mathrm{C}$ (Table 1) that brings the total mass loss up to a magnitude $(35 \%)$ rather close to that $(36.1 \%)$ expected for the overall transformation of $\mathrm{Rb}\left(\mathrm{CH}_{3} \mathrm{COO}\right)$ into $\mathrm{Rb}_{2} \mathrm{O}$. The IR spectrum in the solid phase (Fig.4) at $900{ }^{\circ} \mathrm{C}$ displayed absorption bands below $700{ }^{\circ} \mathrm{C}$ related to lattice modes of vibrations of the oxide $\mathrm{Rb}_{2} \mathrm{O}^{(27)}$.

As a consequence of the above results and discussion, not all of the volatile compounds $\left(\mathrm{H}_{2} \mathrm{O},\left(\mathrm{CH}_{3}\right)_{2} \mathrm{CO}, \mathrm{CH}_{2}=\mathrm{C}=\mathrm{O}, \mathrm{CH}_{3} \mathrm{COOH},\left(\mathrm{CH}_{3}\right)_{2} \mathrm{C}=\mathrm{CH}_{2}, \mathrm{CH}_{4}, \mathrm{CO}_{2}\right.$ and $\mathrm{CO}$ ) identified in the gas phase are primary products of $\mathrm{Rb}\left(\mathrm{CH}_{3} \mathrm{COO}\right)$ decomposition into $\mathrm{Rb}_{2} \mathrm{O}$, since some of them are secondary products formed as a result of side surface reactions involving primary ones.

\section{Conclusion}

The above presented and discussed results may help drawing the following conclusions:

(1) Calcination at $\geq 600{ }^{\circ} \mathrm{C}$ of rubidium acetate, $\mathrm{Rb}\left(\mathrm{CH}_{3} \mathrm{COO}\right)$, results in the formation of crystallized rubidium carbonate, $\mathrm{Rb}_{2}\left(\mathrm{CO}_{3}\right)$ while calcination at $\geq$ 900 , results in the formation of the corresponding oxide, $\mathrm{Rb}_{2} \mathrm{O}$. The formation of the intermediate and final product may be explained by the following pathway:

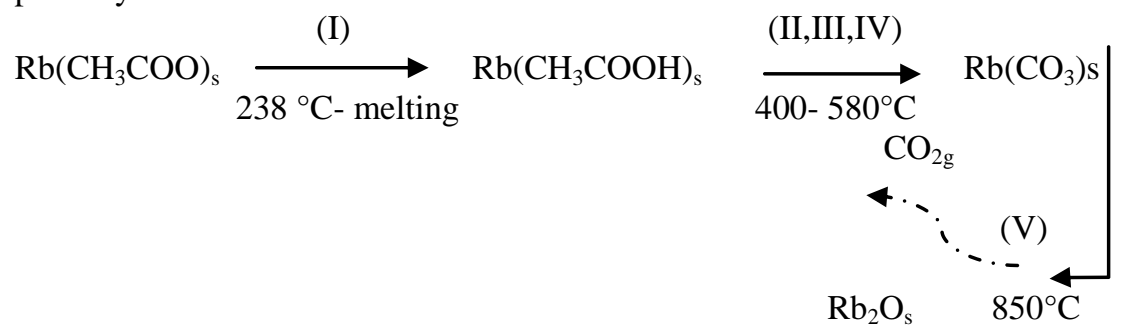

(2)The gas/solid interfacial reactions throughout the decomposition course may help making useful conclusions about the catalytic properties of the associated solid products. The release of small proportions of acetic acid molecules into the gas phase at $200{ }^{\circ} \mathrm{C}$ is, thus, due to hydrolysis of surface acetates and/or hydration of pyrolytically formed ketene $\left(\mathrm{CH}_{2}=\mathrm{C}=\mathrm{O}\right)$ molecules.

(3) Observed decomposition gas phase products are not always those formed directly in the initial stages, and may be due to reactions between the primary products.

(4) Accordingly, Rubidium carbonate $\mathrm{Rb}_{2}\left(\mathrm{CO}_{3}\right)$, obtained by calcination at 500 $650{ }^{\circ} \mathrm{C}$ of the present test acetate, may actively catalyze ketonization of acetic acid molecules in the gas phase as well as the cracking of acetone into methane.

Egypt. J. Chem. 54, No. 4 (2011) 


\section{References}

1. Hussein, G.A.M., Formation of praseodymium oxide from the thermal decomposition of hydrated praseodymium acetate and oxalate. J. Anal. and Appl. Pyrolysis, 37, 111 (1996).

2. Trimm, D.L., Design of Industrial Catalysts, Chemical Engineering Monographs 11, Elsevier,Amsterdam (1980).

3. Ertl, G., Knözinger, H. and Weitkamp, J. (Ed.), Handbook of Heterogeneous Catalysis, Vol. 5, Wiley V.C.H., Weinheim (1997).

4. Brown, M.E., Dollimore, D. and Galwey, A.K., Reactions in The Solid State, Comprehensive Chemical Kinetics, Vol. 22, Elsevier, Amsterdam (1980).

5. Hussein, G.A.M., Meckhemer, G.M. and Balboul, B.A.A., Formation and surface characterization of thulium oxide catalysts. J. Phys.Chem. Chem. Phys. 2, 2033 (2000).

6. Hussein, G.A.M. and Gates, B.C., Characterization of porous lanthanum oxide catalysts microscopic and spectroscopic studies. J. Chem. Soc. Faraday Trans. I. 92, 2425 (1996).

7. Hussein, G.A.M., Nohman, A.K.H. and Attyia, K.M.A., Characterization of the decomposition course of nickel acetat tetrahydrate in air. J. Thermal Anal. 42, 1155 (1994).

8. Balboul, B.A.A., Synthesis course and surface properties of praseodymium oxide obtained via thermal decomposition of praseodymium acetate: Impacts of the decomposition atmosphere. J. Anal. and Appl. Pyrolysis, 88,192 (2010).

9. Mansour, S.A.A., Hussein G.A.M. and Zaki M.I., Decomposition of $\mathrm{Cd}\left(\mathrm{CH}_{3} \mathrm{COO}\right)_{2}$. $2 \mathrm{H}_{2} \mathrm{O}$ and creation of reactive solid surfaces-A spectrothermal investigation. Reactivity of Solids, 8, 197 (1990).

10. Mekhemer, G.A.H., Halawy, S.A., Mohamed M.A. and Zaki, M.I., Ketonization of acetic acid vapour over polycrystalline magnesia: in situ Fourier transform infrared spectroscopy and kinetic studies. J. Catal. 230, 109 (2005).

11. Balboul, B.A.A. and Zaki, M.I., Thermal decomposition course of $\mathrm{Eu}\left(\mathrm{CH}_{3} \mathrm{COO}\right)_{3} \cdot 4 \mathrm{H}_{2} \mathrm{O}$ and the reactivity at the gas/solid interface thus established. Journal of Analytical and Applied Pyrolysis, 89, 95 (2010).

12. Galwey, A.K., Mckee, S.G., Mitchell, T.R.B., Brown, M.E. and Bean, A.F., A kineticand mechanistic study of the thermal decomposition of nickel malonate. Reactivity of Solids, 6, 187 (1988) .

13. Tsuchiya, S., Takase, S. and Imamura, H., Superbasicity of rubidium oxide and caesium oxide, and their reaction profiles of isomerization of butanes. Chem. Lett. 661(1984).

14. Spivey J. J., Catalysis, Vol. 15, Royal Society of Chemistry, p. 42 (2000). 
15. Karagöz, S., Bhaskar, T., Muto, A. and Sakata, Y., Effect of Rb and Cs carbonates for production of phenols from liquefaction of wood biomass .Fuel, 83, 2293 (2004).

16. Standard diffraction data JCPDS files, International Center for Diffraction Data, Newton Square, PA 19073-3273, USA.

17. Peri, J.B. and Hannan, B.H., Surface hydroxyl groups on $\gamma$ - Alumina. J. Phys.Chem. 64, 1526 (1960).

18. Nakamoto K., Infrared Spectra of Inorganic and Coordination Compounds, $2^{\text {nd }}$ ed., Wiley-Interscience, New York (1970).

19. Gadsden, J.A., Infrared Spectra of Minerals and Related Inorganic Compounds. Butteworths, London (1975).

20. Herzberg, G., Molecular Spectra and Molecular Structure. II: Infrared and Raman Spectra of Polyatomic Molecules, ${ }^{\text {th }}$ ed., Van Nostrand, London (1959).

21. Zaki, M.I., Hasan, M.A., Al-Sgheer, F.A. and Pasupulety, L., Surface chemistry of acetone on metal oxides: IR observation of acetone adsorption and consequent surface reactions on silica- alumina versus silica and alumina. Langmuir, 16, 430 (2000).

22. Zaki, M.I., Hasan, M.A. and Pasupulety L., In Situ FTIR spectroscopic study of 2propanol adsorbtive and catalytic interactions on metal modified aluminas. Langmuir, 17, 768 (2001).

23. Parida, K.M., Samal, A. and Das, N.N., Catalytic ketonization of monocar $\square$ ylic acids over Indian Ocean manganese nodules. Appl. Catal. A 166, 201(1998).

24. Glinski, M. and Kaszubski, M., Catalytic ketonization over oxide catalysts, Part IV. Cycloketonization of diethyl hexanodiate. React. Kinet. Catal. Lett. 70, 271(2000).

25. Zaki, M.I. and Sheppard, N., An infrared spectroscopic study of the adsorption and mechanism of surface reactions of 2-propanol on ceria. J. Catal. 80, 114(1983).

26. Zaki, M.I., Hasan M.A. and Pasupulety, L., In situ FTIR spectroscopic study of 2propanol adsorptive and catalytic interactions on metal- modified aluminas. Langmuir, 17, 4025 (2001).

27. MDevitt, N.T. and Baun W.L., Spectrochim. Acta, 20, 799 (1964). 


\section{تحضير كاربونات روبديوم ذو سطح نشط من التحليل الحرارى

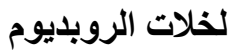

بسمة على بلبول

$$
\text { قسم الكيمياء - كلية العلوم - جامعة المنيا- المنيا - مصر . }
$$

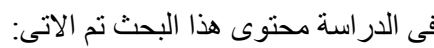

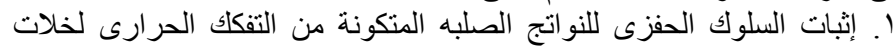

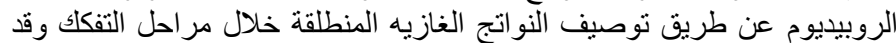

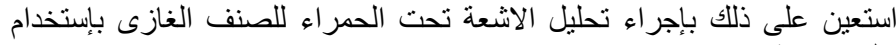

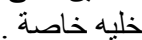

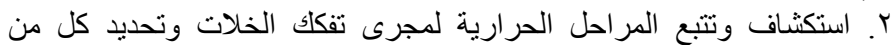

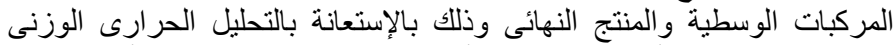

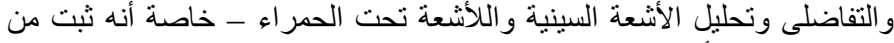

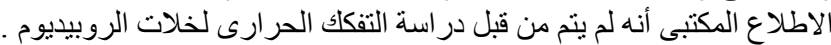

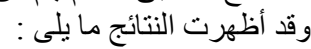

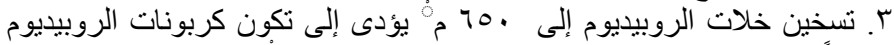

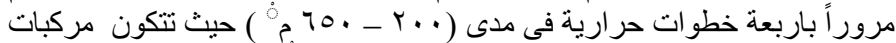

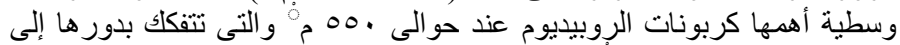

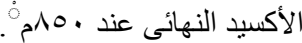

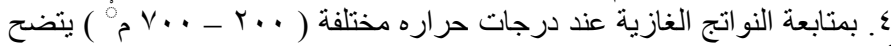

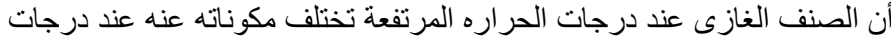

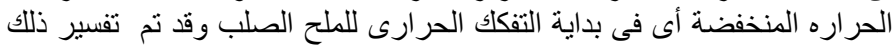

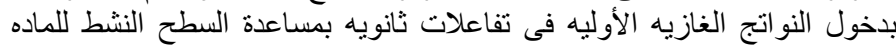

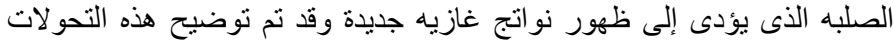
بالمعادلات الكيميائية المئي

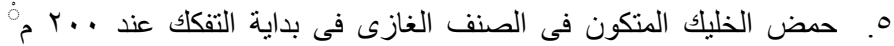

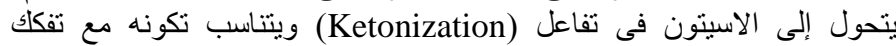
الخلات إلى الكربونات و وأكسيد الروبيديوم حيث يكون سطح الماده الصلبه مهياً بالمر اكز النشطه التى تقوم بدور ها فى إتمام هذه التفاعلات 